\title{
Association of Serum Ferritin Level with Acute Coronary Syndrome
}

\author{
Abu Thaher Mohammad Mahfuzul Hoque1, H. I. Lutfur Rahman Khan², Abdul Wadud Chowdhury³, Md. Mohshin Ahmed ${ }^{4}$ \\ Khandker Md. Nurus Sabah ${ }^{5}$, Md. Gaffar Amin ${ }^{6}$, Md. Solaiman Mia7 , Chowdhury Mohammad Omar Faruque ${ }^{8}$
}

\begin{abstract}
:
Background: A substantial number of patients get admitted in different hospitals of Bangladesh with the diagnosis of acute coronary syndrome (ACS). No underlying conventional risk factors can be identified in significant number of these patients. Therefore new emerging risk factors are likely to be involved in these patients. As many authors reported that high serum ferritin levels are associated with diabetes mellitus (DM) and hypertension (HTN), it may have role in the pathogenesis of ACS.So we designed this study to test the relation between hyperferritinemia and newly diagnosed acute coronary syndrome patients of Bangladesh.
\end{abstract}

Methods: The study was an observational case control study done in Department of Cardiology, Dhaka Medical College Hospital, from January 2013 to December 2013. Newly diagnosed patients with acute coronary syndrome (ACS) in the age group of 30-70 years, admitted in the coronary care unit (CCU) of Dhaka Medical College Hospital, Dhaka, within the study period were taken as cases and age\& sex matched healthy subject with no history of ischemic heart disease (IHD) and with normal ECG were taken as control by purposive sampling. In our study, the number of cases and controls were 65 each. So, total number of subject was 130 .

Results: According to the serum ferritin level both cases and controls were divided into two sub groups: subjects with normal ferritin level and with hyperferritinaemia. Normal ferritin level was found in $35(53.8 \%)$ subjects of case group and $62(95.4 \%)$ subjects of control groups. Hyperferritinaemia was found in $30(46.2 \%)$ subjects of case group and $3(4.6 \%)$ subjects of control group. Hyperferritinaemia was found to be significantly higher in case group than in control group $(p<0.001)$.

Conclusion: The study concludes that the serum ferritin level of patients with ACS was significantly higher than the control group

Key wards: Acute coronary syndrome, Risk Factor, Ferritin.

(Bangladesh Heart Journal 2017; 32(2) : 89-93)

Introduction:

Coronary artery disease (CAD) has become a major health problem and is one of the most common causes of mortality

\& morbidity in the entire world ${ }^{1}$. Among the coronary artery diseases, acute coronary syndrome (ST segment elevation

1. Assistant Professor, Department of Cardiology,Dhaka Medical College, Dhaka, Bangladesh.

2. Ex.Professor \& Head, Department of Cardiology,Dhaka Medical College, Dhaka, Bangladesh.

3. Professor \& Head, Department of Cardiology,Dhaka Medical College, Dhaka,Bangladesh.

4. Asso. Professor, Department of Cardiology,Dhaka Medical College, Dhaka, Bangladesh.

5. Assoc.Professor, Department of Cardiology, Mughda Medical College, Dhaka, Bangladesh.

6. Professor, Department of Cardiology, Dhaka Medical College, Dhaka, Bangladesh.

7. Consultant, Adhunik Sadar Hospital, Habiganj, Bangladesh

8. Emergengy department, Sylhet MAG Osmani Medical College Hospital, Sylhet, Bangladesh.

Address of Correspondence: Dr. Abu Thaher Mohammad Mahfuzul Hoque, Asstistant Professor,Department of Cardiology,Dhaka Medical College Hospital, Dhaka, Bangladesh. Cell No: 01715003523, E-mail:mahfuzmymensingh@gmail.com 
myocardial infarction, non-ST segment elevation myocardial infarction and unstable angina) is the leading cause of death in the developed countries \& second leading cause of death in developing countries .By the year 2020, ischemic heart disease (IHD) will hold first place in the WHO's list of leading causes of disability ${ }^{2}$. Acute coronary syndrome a multifactorial disease, involves well-known risk factors such as age, male sex, smoking, hypertension, diabetes mellitus, dyslipidemia, obesity, family history of premature CAD \& sedentary lifestyle.

There are several studies from developed countries on analysis of major risk factors of ACS; such studies are quite scanty in Bangladesh ${ }^{3}$. The conventional risk factors such as smoking, hypertension, diabetes mellitus, hypercholesterolemia \& positive family history can no longer be said to account for all atherosclerotic CADs now-a-days. Eikelboom et al (1999)suggested that only one half to twothirds of risk for atherosclerotic vascular disease can be explained by classic risk factors ${ }^{4}$. Evaluation of major coronary risk factors in Indian patients undergoing angiography has shown that in about one-third of the patients no major risk factors are detectable, yet they suffer from the dreaded disease; therefore, the identification of newer risk factors is under active consideration ${ }^{5}$ Ferritin is an intracellular protein that stores iron and releaseitin controlled fashion. It reflectsthe amount of iron stored. Free iron acts as a catalyst for the production of free radicals which has been implicated in lipid peroxidation and atherosclerosis leading to acute coronary syndrome ${ }^{6}$. The role of ferritin in pathogenesis of coronary artery disease (CAD) like acute coronary syndrome (ACS) has generated considerable interest in recent times. High serum ferritin levels have been found to be associated with established conventional risk factors of CAD like diabetes mellitus (DM) and hypertension (HTN) by various authors ${ }^{7}$. There is a plethora of articles reporting the relationship between serum ferritin and ACS but with conflicting results. Sullivan (1981) was the first to observe that high level of stored iron is a risk factor for ischemic heart disease ${ }^{8}$. Subsequently results of various studies showed statistically significant association of high serum ferritin with acute coronary syndrome ${ }^{9}$. After extensive literature search we found no published article testing the relationship of high serum ferritin level with acute coronary syndrome in Bangladeshi population.

\section{Methods:}

This observational case control study was conducted in the Department of Cardiology of Dhaka Medical College Hospital during a period of one year from January 2013 to December2013.Patients with suspected ACS admitted through emergency or outpatient department into $\mathrm{CCU}$, department of Cardiology of Dhaka Medical College Hospital, were first assessed by the attending doctor and then evaluated by the principal investigator.12 lead standard surface ECG and cardiac biomarker (Troponin-I) were done. Detailed history was taken and physical examination was done and required data were recorded in preformed data collection sheet. Newly diagnosed patients with acute coronary syndrome (ACS) in the age group of 30-70 years were taken as cases and age \& sex matched healthy subjects (doctors, medical students, nurses \& other hospitalstaffs and patient's attendants from DMCH, Dhaka) within the study period with no history of ischemic heart disease (IHD) and with normal ECG were taken as control by purposive sampling. In this study, the number of cases and number of control were 65 each. So, total number of subject was 130 . Informed consent was taken from the study subject or from the legal guardians before enrolling them in the study. All the study subjects were evaluated for demographic profile (age \& sex) and risk factors for coronary artery disease like diabetes, hypertension, dyslipidemia, smoking, overweight/obesity, and family history of premature coronary artery disease $(C A D)$ were recorded. Baseline investigations e.g. ECG was done and fasting lipid profile, fasting blood sugar and serum ferritin were estimated for all cases and controls. Serum ferritin was done by using XYEM enzymelinked immunosorbent assay (ELISA) test using ELISA reader. Comparison of serum ferritin levels was done between cases and controls and the association of serum ferritin levels with ACS was studied.

All the information was properly noted in the preformed data collection sheet.Data were analyzed by using SPSS version 16. The continuous data were expressed as mean \pm standard deviation (SD). The difference of mean of continuous variables between two groups were calculated byStudents $t$ test. To determine the independent association of serum ferritin with ACS, initially univariate analysis was done followed by multivariate logistic regression analysis, with ACS as a dichotomous independent outcome variable. The categorical variables (discrete data) were expressed as frequency and percentage. The difference of categorical variables between two groups were calculated by chi-square $\left(C^{2}\right)$ test. Level of significance was set at 0.05 . Risk analysis were carried out by calculating odds ratio (OR) and $95 \%$ confidence interval $(\mathrm{Cl})$.

\section{Results:}

This observational case-control study enrolled 65 newly diagnosed patients with acute coronary syndrome (ACS) in the age group of 30-70 years, admitted in the coronary care unit (CCU) of Dhaka Medical College Hospital, Dhaka within the study period. They were designated as case group. Age 
and sex matched 65 healthy subjects (doctors, medical students, nurses and other hospital-staffs and patient's attendants) with no history of ischemic heart disease (IHD) and normal ECG were taken as control. The comparison between mean of serum ferritin between two groups was done by Student $t$ test and comparison of proportions of serum ferritin between two groups was done by chi-square test. $P$ value $<0.05$ was considered significant.

Among the subjects of case group, maximum number of subjects belongs to the age group of $50-59$ years (38.5\%) followed by age group of $60-69$ years $(29.2 \%)$. Among the subjects of control group, maximum number of subjects belongs to the age group of $40-49$ years and $50-59$ years (29.2\% in each) followed by age group of 60-69 years $(27.7 \%)$. In cases the mean age was $52.65 \pm 9.44$ years and in controls the mean age was $50.94 \pm 10.38$ years. The difference of mean ages between the case and control groups was not statistically significant. $(\mathrm{p}=0.328)$ (Table-I).

Among cases $44(67.7 \%)$ were male and $21(32.3 \%)$ were female, among the controls $44(67.7 \%)$ were male and $21(32.3 \%)$ were female. The difference in sex between groups was not statistically significant $(p=0.463)$ (Table-II).

According to serum ferritin level both cases and controls were divided into two sub groups: subjects with normal ferritin level (d"300 $\mu \mathrm{g} / \mathrm{L}$ in male, d" $200 \mu \mathrm{g} / \mathrm{L}$ in female)and with hyperferritinaemia ( $>300 \mu \mathrm{g} / \mathrm{L}$ in male, $>200 \mu \mathrm{g} / \mathrm{L}$ in female).Normal ferritin level was found in $35(53.8 \%)$ subjects of case group and 62(95.4\%) subjects of control groups. Hyperferritinaemia was found in $30(46.2 \%)$ subjects of case group and $3(4.6 \%)$ subjects of control group. Hyperferritinaemia was found to be significantly higher in case group than in control group $(p<0.001)$.

The mean $\pm S D$ serum ferritin level was also higher in case group then controls group $(225.15 \pm 164.05 \mu \mathrm{g} / \mathrm{L}$ in case group and $83.97 \pm 60.61 \mu \mathrm{g} / \mathrm{L}$ in control group). ( $p<0.001$ ) (Table III).

Hyperferritinaemia was found in $30(46.2 \%)$ subjects of case group and $3(4.6 \%)$ subjects of control group. Normal ferritin level was found in $35(53.8 \%$ ) subjects of case group and 62(95.4\%) subjects of control group. The difference was statistically significant $(p<0.001)$. During risk assessment of ferritin concentration for ACS development, it was found that high serum ferritin was strongly associated with ACS risk having OR=7.031 (95\% Cl=2.366-20.896) (table IV)Risk factors analysis for ACS by multivariate logistic regression showssmoking, hypertension, diabetes, family history of premature $C A D$ and hyperferritinaemia, were found to be significantly $(p<0.05)$ associated with ACS-risk. However, dyslipidaemia and obesity/overweight were not found to be significantly associated with ACS risk ( $p>0.05)$. (Table V).
Table I

Age distribution of the study subjects $(n=130)$

\begin{tabular}{|c|c|c|c|c|c|c|c|}
\hline \multirow[t]{2}{*}{$\begin{array}{l}\text { Age in } \\
\text { years }\end{array}$} & \multicolumn{2}{|c|}{$\begin{array}{l}\text { Case group } \\
\qquad(n=65)\end{array}$} & \multicolumn{2}{|c|}{$\begin{array}{l}\text { Control group } \\
\qquad(n=65)\end{array}$} & \multicolumn{2}{|c|}{$\begin{array}{c}\text { Total } \\
(n=130)\end{array}$} & \multirow{2}{*}{$\begin{array}{l}\text { P value } \\
\text { b0.163 NS }\end{array}$} \\
\hline & $f$ & $\%$ & $f$ & $\%$ & $f$ & $\%$ & \\
\hline 30-39 & 4 & 6.2 & 9 & 13.8 & 13 & 10.0 & \\
\hline $40-49$ & 14 & 21.5 & 19 & 29.2 & 33 & 25.4 & \\
\hline $50-59$ & 25 & 38.5 & 19 & 29.2 & 44 & 33.8 & \\
\hline $60-69$ & 19 & 29.2 & 18 & 27.7 & 37 & 28.5 & \\
\hline 70 or more & 3 & 4.6 & 0 & 0.0 & 3 & 2.3 & \\
\hline Mean $\pm S D$ & \multicolumn{2}{|c|}{$52.65 \pm 9.44$} & \multicolumn{2}{|c|}{$50.94 \pm 10.38$} & \multicolumn{2}{|c|}{$51.79 \pm 9.92$} & ${ }^{\mathrm{a}} 0.328^{\mathrm{NS}}$ \\
\hline $\begin{array}{l}\text { Range } \\
\text { (min-max) }\end{array}$ & \multicolumn{2}{|c|}{$30-70$} & \multicolumn{2}{|c|}{$30-66$} & \multicolumn{2}{|c|}{$30-70$} & \\
\hline
\end{tabular}

NS $=$ not significant

$a=P$ value derived from unpaired $t$ test; $b=P$ value derived from chisquare test

Table-II

Sex distribution of study subjects $(n=130)$

\begin{tabular}{|c|c|c|c|c|c|c|c|}
\hline \multirow[t]{2}{*}{$\begin{array}{l}\text { Sex of } \\
\text { the subjects }\end{array}$} & \multicolumn{2}{|c|}{$\begin{array}{l}\text { Case group } \\
\quad(n=65)\end{array}$} & \multicolumn{2}{|c|}{$\begin{array}{l}\text { Control group } \\
\quad(n=65)\end{array}$} & \multicolumn{2}{|c|}{$\begin{array}{c}\text { Total } \\
(n=130)\end{array}$} & \multirow[t]{2}{*}{$P$ value } \\
\hline & $f$ & $\%$ & $f$ & $\%$ & f & $\%$ & \\
\hline & $f$ & $\%$ & $f$ & $\%$ & $f$ & $\%$ & $\mathrm{~b} 1.000^{\mathrm{NS}}$ \\
\hline Male & 44 & 67.7 & 44 & 67.7 & 88 & 67.7 & \\
\hline Female & 21 & 32.3 & 21 & 32.3 & 42 & 32.3 & \\
\hline
\end{tabular}

$\mathrm{NS}=$ not significant

$b=P$ value derived from Chi-square test

Table III

Distribution of the study subjects according to serum ferritin level $(n=130)$

\begin{tabular}{|c|c|c|c|c|c|c|c|}
\hline \multirow{2}{*}{$\begin{array}{l}\text { Serum } \\
\text { ferritin level }\end{array}$} & \multicolumn{2}{|c|}{$\begin{array}{l}\text { Case group } \\
\qquad(\mathrm{n}=65)\end{array}$} & \multicolumn{2}{|c|}{$\begin{array}{c}\text { Control group } \\
(n=65)\end{array}$} & \multicolumn{2}{|c|}{$\begin{array}{c}\text { Total } \\
(n=130)\end{array}$} & \multirow{2}{*}{$\begin{array}{l}\text { Pvalue } \\
a<0.001^{s}\end{array}$} \\
\hline & $f$ & $\%$ & $f$ & $\%$ & $f$ & $\%$ & \\
\hline $\begin{array}{l}\text { Normal } \\
\text { ferritin level }\end{array}$ & 35 & 53.8 & 62 & 95.4 & 97 & 74.6 & \\
\hline $\begin{array}{l}\text { Hyper- } \\
\text { ferritinaemia }\end{array}$ & 30 & 46.2 & 3 & 4.6 & 33 & 25.4 & \\
\hline $\begin{array}{l}\text { Mean } \pm S D \\
(\mu \mathrm{g} / \mathrm{L})\end{array}$ & \multicolumn{2}{|c|}{$\begin{array}{c}225.15 \pm \\
164.05\end{array}$} & \multicolumn{2}{|c|}{$\begin{array}{c}83.97 \pm \\
60.61\end{array}$} & \multicolumn{2}{|c|}{$\begin{array}{c}154.56 \pm \\
142.11\end{array}$} & \\
\hline $\begin{array}{l}\text { Range } \\
\text { (min-max) }\end{array}$ & \multicolumn{2}{|c|}{$\begin{array}{c}(5.60- \\
580.00)\end{array}$} & \multicolumn{2}{|c|}{$\begin{array}{l}(20.00- \\
305.00)\end{array}$} & \multicolumn{2}{|c|}{$\begin{array}{c}(5.60- \\
580.00)\end{array}$} & $b<0.001^{s}$ \\
\hline
\end{tabular}

Normal ferritin level, $\leq 300 \mu \mathrm{g} / \mathrm{L}$ in male, $\leq 200 \mu \mathrm{g} / \mathrm{L}$ in female; Hyperferritinaemia, $>300 \mu \mathrm{g} / \mathrm{L}$ in male, $>200 \mu \mathrm{g} / \mathrm{L}$ in females $=$ Significant,

$a=p$ value derived from chi square test $b=p$ value derived from unpaired t test 
Table-IV

Risk assessment of serum ferritin concentration for ACS (N==130)

\begin{tabular}{|c|c|c|c|c|c|c|c|}
\hline \multirow[t]{2}{*}{ Serum ferritin level $(\mu \mathrm{g} / \mathrm{L})$} & \multicolumn{2}{|c|}{$\begin{array}{c}\text { Case group } \\
(n=65)\end{array}$} & \multicolumn{2}{|c|}{$\begin{array}{c}\text { Control group } \\
(\mathrm{n}=65)\end{array}$} & \multirow[t]{2}{*}{$\begin{array}{l}\text { Odds Ratio } \\
\text { (OR) }\end{array}$} & \multirow[t]{2}{*}{$\begin{array}{l}95 \% \mathrm{Cl} \\
\text { for OR }\end{array}$} & \multirow[t]{2}{*}{ Pvalue } \\
\hline & $f$ & $\%$ & $f$ & $\%$ & & & \\
\hline Normal ferritin level & 35 & 53.8 & 62 & 95.4 & 17.7 & $2.366-20.896$ & $<0.001^{\mathrm{S}}$ \\
\hline Hyperferritinaemia & 30 & 46.2 & 3 & 4.6 & & & \\
\hline
\end{tabular}

Normal ferritin level, $\leq 300 \mu \mathrm{g} / \mathrm{L}$ in male, $\leq 200 \mu \mathrm{g} / \mathrm{L}$ in female;

Hyperferritinaemia, $>300 \mu \mathrm{g} / \mathrm{L}$ in male, $>200 \mu \mathrm{g} / \mathrm{L}$ in female,

$\mathrm{S}=$ Significant

Table-V

Risk factors analysis for ACS (multivariate logistic regression models) ( $N=130)$

\begin{tabular}{lcccc}
\hline Risk factors & Regression coefficient & \multicolumn{2}{c}{$95 \%$ Cl for Regression coefficient } & \multirow{2}{*}{ P value } \\
\cline { 3 - 4 } & & Lower & 32.124 & $<0.001^{\mathrm{S}}$ \\
\hline Smoker & 2.28 & 2.991 & 104.034 & $0.001^{\mathrm{S}}$ \\
Hypertension & 2.945 & 3.473 & 24.590 & $.013^{\mathrm{S}}$ \\
Diabetes mellitus & 1.792 & 1.465 & 25.425 & $.024^{\mathrm{S}}$ \\
Family history of premature CAD & 1.731 & 1.253 & 5.181 & $.498^{\mathrm{NS}}$ \\
Dyslipidaemia & 0.423 & 0.449 & 6.207 & $.495^{\mathrm{NS}}$ \\
Obesity/ Overweight & .471 & .414 & .498 & $.004^{\mathrm{S}}$ \\
S ferritin status & 2.187 & .025 & &
\end{tabular}

Risk factors analysis for ACS by multivariate logistic regression showssmoking, hypertension, diabetes, family history of premature CAD and hyperferritinaemia, were found to be significantly $(p<0.05)$ associated with ACS-risk. However, dyslipidaemia and obesity/overweight were not found to be significantly associated with ACS risk ( $p>0.05)$.

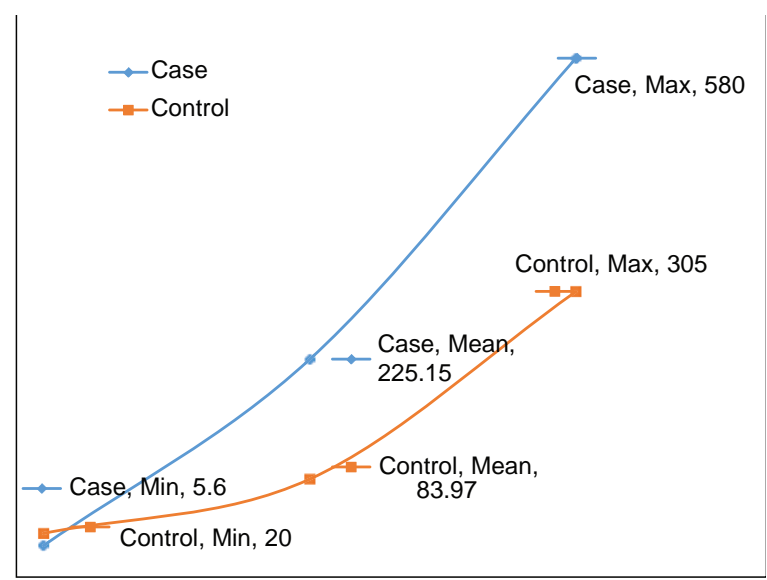

Fig.-1: Line diagram showing mean, maximum and minimum distribution of serum ferritin level $(\mu \mathrm{g} / \mathrm{L})$ of the study subjects $(N=130)$.

\section{Discussion:}

This observational case-control study was carried out with an aim to find out the association between serum ferritin concentration and acute coronary syndrome (ACS). A total of 130 study subjects were studied. Among them 65 subjects had ACS (ST segment elevation myocardial infarction, NonST segment elevation myocardial infarction and Unstable angina) admitted in CCU, Department of Cardiology, DMCH, Dhaka and rest 65 were healthy subjects who were age and sex matched controls. Serum ferritin level and traditional risk factors for ACS were documented from all the study subjects.

In this study most of the ACS patients were between 40 to 69 years. However $10 \%$ patients were below 40 years of age.The mean age of the case and control groups was similar $(p=0.328)$.

Most of the patients were male 88 in number $(67.7 \%)$ and number of female were $42(32.3 \%)$ which is consistent with many other studies ${ }^{10-16} .(p=1.000)$.

This study showed serum ferritin level was significantly higher in ACS patients (46.2\% in case group vs. $4.6 \%$ in control group) $(p=<0.001)$ 


\section{References:}

1. Pinto'X, Mill'an J, MunozA et al. A very high prevalence of low HDL-C in Spanish patients with ACS. Clin Cardiol 2010; 33:418-423.

2. Murrary CJ and LopezAD. Mortality by cause for eight regions of the world: global burden of disease study. Lancet 1997; 349:1269-1276.

3. Khan AR, Islam AEM M, Ali M, et al. Study of risk factors and coronary angiographic pattern in younger patients with acute coronary syndrome. Bangladesh Heart Journal.2004; 19(2): 109-119.

4. Eikelboom JW, Lorin E, Genest J Jr, et al. Homocysteine and cardiovascular disease: A critical review of the epidemiological evidence. Ann Intern Med 1999; 131:363-375

5. Islam MF. Acute myocardial infarction in young adults: (Risk factors and early prognosis) a comparative clinical study with elderly patients [thesis]. Dhaka University, Dhaka 1989.

6. Oliver ME Antioxidant nutrients, atherosclerosis and coronary heart disease. Br Heart J 1995; 73:299-301

7. Haidari M, Javadi E, Sanati A. Association of increased ferritin with premature coronary stenosis in men. Physiol Genomics 2003; 13:25-30.

8. Sullivan JL. Iron and the Sex Difference in Heart Disease Risk. The Lancet 1981; 317: 1293-1294.

9. Delphine W, Silvia CR, Biswas S, Uthappa S, Shetty P.Ferritin-a potent threat for acute myocardial infarction. J Assoc Physicians (India) 2003; 51:947-50.

10. Iqbal MP, Mehboobali N, Tareen AK, Yakub M, Iqbal SP, Iqbal K, Haider G. Association of Body Iron Status with the Risk of Premature Acute Myocardial Infarction in a Pakistani Population. PLOS ONE 2013; 8:e67981.11. Reunanen A, Takkunen H, Knekt P, Seppanen R, Aromaa A. Body iron stores, dietary iron intake and coronary heart disease mortality. J Intern Med 1995; 238:223-30.

12. Solymoss BC, Marcil M, Gilfix BM, Gelinas F, Poitras AM, Campeau L. The place of ferritin among risk factors associated with coronary artery disease. Coron Artery Dis1994; 5:231-5.

13. Kraml P, Potockova J, Koprivova H, Stípek S, Crkovska J, Zima T, Andel M. Ferritin, oxidative stress and coronary atherosclerosis. Vnitr Lek 2004; 50:197-202.

14. Silvia CRWD, Sharmistha Biswas S, Uthappa S, Shetty P. Ferritin, a Potent Threat for Acute Myocardial Infarction? JAPI 2003; 947-950.

15. Kiechl S, Willeit J, Egger G, Poewe W and Oberhollenzer $F$ for the Bruneck Study Group. Body Iron Stores and the Risk of Carotid Atherosclerosis; Prospective Results from the Bruneck Study. Circulation. 1997; 96: 3300-3307.

16. Holay MP, Choudhary AA and Suyawanshi SD. Serum ferritin-a novel risk factor in acute myocardial infarction. Indian Heart J 2012; 64:173-7. 